\title{
PENGEMBANGAN PERANGKAT PEMBELAJARAN PADA MATERI SEGIEMPAT MELALUI PENDEKATAN OPEN-ENDED UNTUK MENINGKATKAN KEMAMPUAN BERPIKIR KREATIF
}

\author{
Yanti $^{1)}$, Sumarni ${ }^{2)}$, Nuranita Adiastuty ${ }^{3)}$ \\ ${ }^{1), 2), 3)}$ Program Studi Pendidikan Matematika FKIP Universitas Kuningan, Jawa Barat; \\ yantiprasetya01@gmail.com ${ }^{1)}, \underline{\text { marnie.1205@gmail.com }}{ }^{2)}$, anitha_dyaz2@yahoo.co.id ${ }^{3)}$
}

\begin{abstract}
The study aims to develop learning devices through an open-ended approach in square material. The learning devices developed consist of student modules and lesson plan (RPP). This study is the research, development model of Plomp with consist of three stages: preliminary research phase, prototype phase and assessment phase. Instrument for data collection that used were pretest and posttest questions, questionnaire of expert validation and questionnaire of student response. The device developed was validated by three validators then conducted a limited trial. From the resulting validation data the average score of student module is 4.33 (valid), the average RPP score is 4.29 (valid). The validator statement against both learning devices developed is usable with little revision and without revision and the student's response to the learning device. was positive (practical). The increase of students ' creative thinking capability of N-Gain of 0.67 with moderate upgrade category. The results of the study were obtained that the device was developed is valid, practical, and can improve creative thinking ability..
\end{abstract}

Keywords : Learning Devices, Open-Ended Approach, Creative Thinking Ability.

ABSTRAK
Penelitian ini bertujuan untuk mengambangkan perangkat pembelajaran melalui
pendekatan open-ended pada materi segiempat. Perangkat pembelajaran yang
dikembangkan terdiri dari modul siswa dan Rencana Pelaksanaan Pembelajaran (RPP).
Penelitian ini merupakan penelitian pengembangan model Plomp yang terdiri dari 3
tahap yaitu fase penelitian pendahuluan, fase pembuatan prototype dan fase penilaian.
Instrumen pengumpulan data yang digunakan adalah soal pretest dan posttest, angket
lembar validasi ahli dan angket respon siswa. Perangkat yang dikembangkan divalidasi
oleh tiga orang validator kemudian dilakukan ujicoba terbatas. Dari hasil validasi
diperoleh data rata-rata skor modul siswa adalah 4,33 (valid), rata-rata skor RPP adalah
4,29 (valid). Pernyataan validator terhadap kedua perangkat pembelajaran yang
dikembangkan adalah dapat digunakan dengan sedikit revisi dan tanpa revisi dan respon
siswa terhadap perangkat pembelajaran adalah positif (praktis). Peningkatan
kemampuan berpikir kreatif siswa memperoleh hasil N-Gain sebesar 0,67 dengan
kategori peningkatan sedang. Hasil penelitian diperoleh bahwa perangkat yang
dikembangkan valid, praktis, dan dapat meningkatkan kemampuan berpikir kreatif.
Kata Kunci : Perangkat Pembelajaran, Pendekatan Open-Ended, Kemampuan Berpikir
Kreatif




\section{PENDAHULUAN}

Sekolah merupakan salah satu pendidikan formal yang didalamnya terdapat kegiatan pembelajaran. Anwar dkk (2015) sekolah merupakan tempat pendidikan formal dimana kegiatan pembelajaran matematika dilaksanakan. Matematika merupakan mata pelajaran yang wajib dipelajari dari berbagai tingkatan pendidikan, hal ini karena matematika selalu digunakan hampir semua disiplin ilmu yang paling tidak memuat perhitungan dasar yaitu penjumlahan, pengurangan, perkalian, dan pembagian.

Menurut Rochmad (Suryadinata, 2015) pada mata pelajaran matematika banyak materi yang dapat mengantarkan siswa memiliki keterampilan berpikir kritis dan kreatif. Dengan demikian matematika dapat membantu meningkatkan kemampuan berpikir kreatif siswa. Menurut Permendikbud No. 20 tahun 2016 juga menyatakan bahwa melalui pendekatan ilmiah suatu pembelajaran termasuk pada mata pelajaran matematika siswa diharapkan memiliki kemampuan berpikir dan bertindak secara kreatif, produktif, kritis, mandiri, kolaboratif, dan komunikatif. Melalui permendiknas ini menunjukan bahwa dalam pembelajaran matematika siswa harus dapat memiliki kemampuan berpikir kreatif. Lestari dan Yudhanegara (2015) kemampuan berpikir kreatif adalah kemampuan untuk menghasilkan ide atau gagasan yang baru dalam menghasilkan suatu cara dalam menyelesaikan masalah, bahkan menghasilkan cara yang baru sebagai solusi alternatif. $\begin{array}{lr} & \text { Wulandari dan Wardano (Dewi, } \\ 2017) \quad \text { mengemukakan } & \text { bahwa } \\ \text { pembelajaran matematika yang }\end{array}$ diterapkan oleh para guru disekolah pada umumnya adalah konvensional yaitu dengan menggunakan pembelajaran langsung atau metode ekspositori dimana guru menjadi pusat dalam kegiatan belajar mengajar yang menyebabkan siswa kurang terlatih untuk mengambangkan kemampuan berpikir kreatif. Hal ini serupa dengan keadaan di salah satu sekolah yang ada di Kuningan bahwa dalam proses pembelajaran masih terpaku kepada guru sebagai pusat pembelajaran di kelas sehingga menyebabkan kemampuan berpikir kreatif siswa rendah.

Untuk dapat meningkatkan kemampuan berpikir kreatif siswa maka dalam proses pembelajaran haruslah dikembangkan sebuah perangkat pembelajaran oleh guru yang memfasilitasi siswa mengembangkan kreativitas yang dimilikinya. Perangakat pembelajaran yang dikembangkan dapat disesuaikan dengan kurikulum yang digunakan Indonesia pada saat ini yaitu kurikulum 2013. Kurikulum 2013 menekankan pada dimensi pedagogik modern dalam pembelajaran, yaitu menggunakan pendekatan ilmiah (Komara dan Dewi, 2017). Pendekatan ilmiah ini mempunyai karakteristik yaitu salah satunya pembelajaran yang berpusat pada siswa (student center). Pelopor tercapainya tujuan pembelajaran salah satunya adalah guru, guru yang efektif harus dapat membuat proses pembelajaran berlangsung secara efektif juga serta guru harus 
mempersiapkan perangkat pembelajaran yang mendukung berlangsungnya kegiatan belajar. Pembelajaran yang efektif merupakan upaya yang dilakukan oleh guru dalam membantu siswanya belajar.

Sebagian guru telah menyusun perangkat pembelajarannya sendiri sesuai dengan kurikulum yang digunakan, akan tetapi sebagian lain dari guru banyak yang menggunakan perangkat pembelajaran yang telah ada atau modul yang banyak dijual di pasaran yang kebanyakan tidak membuat siswa mengkonstruksi konsep sendiri dan menggunakan tipe soal tertutup. Hal ini seperti dikemukakan Anwar dkk (2015) bahwa guru cenderung menggunakan buku paket yang telah ada tanpa usaha untuk membuat atau mengembangkan yang lainnya. Masalah tersebut juga terdapat pada salah satu sekolah yang ada di kabupaten Kuningan yang dapat dilihat melalui gambar berikut:

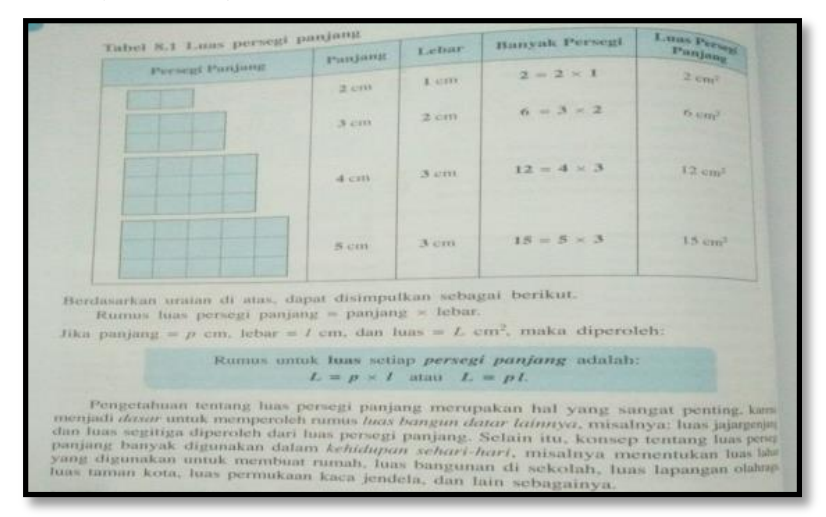

Sumber: (Adinawan, 2016)

Gambar 1. Permasalahan Bahan Ajar Siswa di Sekolah

Pada gambar 1. di atas terlihat bahwa bahan dalam bahan ajar tersebut tidak memberikan kesempatan kepada siswa untuk menemukan rumus luas persegi panjang sendiri dengan menggunakan berbagai metode atau cara penyelesaian, akan tetapi dalam bahan ajar tersebut langsung diberikan rumus luas dari persegi panjang sehingga pemahaman siswa terhadap materi yang disajikan kurang.

Jika hal tersebut terus terjadi maka pengetahuan siswa mengenai materi yang diajarkan menjadi kurang dipahami dan siswa tidak dapat mengeksplorasi pengetahuan yang dimilikinya dalam menyelesaikan soal dengan berbagai metode atau cara sehingga kemampuan berpikir kreatif matematis siswa akan rendah. Dengan demikian perlu dikembangkan perangkat pembelajaran yang dapat mengkonstruksi pengetahuan oleh siswa sendiri dengan menggunakan banyak metode atau cara yang dimiliki siswa sehingga merangsang kemampuan berpikir kreatif siswa dalam menyelesaikan permasalahan yang diberikan. Perangkat pembelajaran yang dapat dikembangkan untuk mengatasi masalah tersebut adalah Rencana Pelaksanaan Pembelajaran (RPP) dan modul pembelajaran siswa. Anwar dkk (2015) keberhasilan suatu proses pembelajaran juga dipengaruhi oleh bagaimana suatu materi disampaikan 
dengan pendekatan serta teknik tertentu. Pendekatan pembelajaran yang sesuai untuk siswa mengkonstruksi konsep sendiri dengan menggunakan berbagai cara atau metode yang dimikinya dan dapat meningkatkan kemampuan berpikir kreatif matematis ialah pendekatan open-ended.

Shimada (Affandi dkk, 2013,

hlm. 4) mengemukakan bahwa pendekatan open-ended adalah pendekatan pembelajaran yang menyajikan suatu permasalahan yang memiliki cara penyelesaian yang benar lebih dari satu, sehingga dapat memberi kesempatan kepada siswa untuk memperoleh pengetahuan/ pengalaman menemukan, mengenali, dan memecahkan masalah dengan beberapa teknik. Melalui pendekatan open-ended siswa dapat mengembangkan ide atau pengetahuan sendiri yang sudah diketahuinya dalam menyelesaikan masalah terbuka dengan berbagai cara sehingga dapat meningkatkan kemampuan berpikir kreatif siswa. Pendekatan open-ended sangat berkaitan dengan pendekatan ilmiah (saintifik) yang digunakan dalam kurikulum 2013 yaitu pembelajaran yang berpusat pada siswa (student center), menurut Rini (2018) pendekatan open-ended merupakan pembelajaran berbasis student center dengan pengajuan masalah. Masalah disini yaitu masalah yang mempunyai banyak jawaban benar atau banyak cara penyelesaian sehingga siswa dapat mengkonstruksi pengetahuan dengan cara sendiri dan dengan berbagai cara penyelesaian.
Dengan adanya perangkat pembelajaran berbasis pendekatan open-ended diharapkan dapat meningkatkan hasil prestasi akademik siswa sehingga mendorong siswa untuk lebih aktif dan kreatif lagi selama proses pembelajaran. Selain itu dengan adanya perangkat pembelajaran yang mendukung proses belajar dapat meningkatkan kualitas pendidikan di Indonesia baik dari sisi pendidik maupun peserta didik.

penelitian yang dilakukan oleh Faridah dkk (2016) menunjukan bahwa peningkatan kemampuan berpikir kreatif matematis dengan pendekatan open-ended. Indraningtias \& Wijaya (2017) mengembangkan perangkat pembelajaran berupa RPP (Rencana Pelaksanaan Pembelajaran) dan LKS (Lembar Kerja Siswa) pada materi bangun ruang sisi datar yang memberikan hasil bahwa perangkat pembelajaran yang dikembangkan efektif untuk meningkatkan kemampuan berpikir kritis siswa.

Berdasarkan penjabaran penjelasan diatas, peneliti tertarik untuk melakukan penelitian pengembangan perangkat pembelajaran pada materi Segiempat melalui pendekatan OpenEnded untuk meningkatkan kemampuan berpikir kreatif.

\section{LANDASAN TEORI}

\section{Kemampuan Berpikir Kreatif}

Lestari \& Yudhanegara (2015) menyatakan bahwa kemampuan berpikir kreatif adalah kemampuan untuk menghasilkan ide atau gagasan yang baru dalam mnghasilkan suatu cara dalam menyelesaikan masalah, bahkan menghasilkan cara yang baru 
sebagai solusi alternatif. Menurut Anwar et al (2012) terdapat 4 aspek dalam berpikir kreatif yaitu fluency (kelancaran), flexybiity (keluwesan), orginality (kebaruan), dan elaboration (keterincian). Keempat aspek tersebut dijelaskan secara rinci oleh Mursidik dkk (2015) yaitu : (1) Aspek Fluency (kelancaran) terkait dengan cara siswa membangun ide. Kelancaran dalam berpikir kreatif mengacu pada beragamnya jawaban benar yang diberikan kepada siswa. Dalam aspek ini, jawaban yang berbeda belum tentu dianggap beragam; (2) Aspek flexibility (keluwesan) mengarah pada kemampuan siswa untuk memecahkan masalah dengan beragam cara penyelesaian yang berbeda. Penggunaan cara yang berbeda ini diawali dengan memandang permasalahan yang diberikan dari sudut pandang yang berbeda; (3) Aspek originality (kebaruan) terkait dengan berapa siswa yang memberikan jawaban atau cara penyelesaian tersebut. Semakin jarang siswa memberikan suatu jawaban yang sama atau cara penyelesaian yang sama, semakin tinggi tingkat keaslian jawaban tersebut. Namun aspek ini juga tetap harus mempertimbangkan kesesuaian dan kemanfaatan jawaban; (4) Aspek elaboration (keterincian) terkait dengan kemampuan siswa untuk menjelaskan secara runtut, rinci dan saling terkait anara satu langkah dengan langkah lainnya. Penggunaan konsep, istilah, dan notasi yang sesuai juga dipertimbangkan dalam aspek ini.

\section{Perangkat Pembelajaran}

Suhadi (Santi dan Santosa, 2016) perangkat pembelajaran adalah sejumlah bahan, alat, media, petunjuk, dan pedoman yang akan digunakan dalam kegiatan pembelajaran. Kemudian Trianto (Ariani dkk, 2013) mengatakan bahwa perangkat pembelajaran adalah perangkat yang digunakan dalam proses pembelajaran, diantaranya: Rencana Pelaksanaan Pembelajaran (RPP), Lembar Kegiatan Siswa (LKS) dan instrument evaluasi atau tes hasil belajar. Dapat disimpulkan bahwa perangkat pembelajaran adalah sejumlah alat bantu yang digunakan dalam kegiatan pembelajaran untuk mencapai tujuan yang diharapkan.

\section{Pendekatan Open-Ended}

Hidayanto dan Khalistin (2013) menyebutkan bahwa pendekatan openended adalah suatu pendekatan pembelajaran dengan menyajikan masalah yang memiliki penyelesaian benar lebih dari satu atau jawaban benar lebih dari satu sehingga siswa secara aktif mengembangkan metode, cara, atau pendekatan yang berbeda untuk menyelesaikan masalah yang diberikan. Shimada (Anwar dkk, 2015) juga mengatakan pendekatan open-ended adalah suatu pendekatan pembelajaran yang dimulai dengan mengenalkan atau menghadapkan siswa pada masalah terbuka atau open-ended problem. Shimada (Soeyono, 2014) juga mendefinisikan masalah terbuka (openended problem) sebagai masalah yang memiliki beberapa jawaban benar, sedangkan masalah atau soal-soal yang hanya memiliki satu jawaban benar dan jawaban selain jawaban tersebut adalah salah, maka masalah tersebut adalah masalah tertutup (closed problem). 
Novtiar \& Aripin (2017) terdapat empat tahapan pendekatan open-ended yaitu: (1) Menghadapkan siswa pada masalah terbuka. (2) Membimbing siswa untuk menemukan pola dan mengkonstruksi pengetahuan atau permasalahannya sendiri. (3) Membiarkan siswa mencari solusi dan menyelesaikan masalah dengan berbagai penyelesaian. (4) Menyajikan hasil temuannya.

\section{METODE PENELITIAN}

\section{Jenis Penelitian}

Penelitian ini menggunakan jenis penelitian desain research dengan mengembangkan perangkat pembelajaran yang terdiri dari Rencana Pelaksanaan Pembelajaran (RPP) dan modul pembelajaran siswa. Plomp (2013) mengemukakan bahwa jenis penelitian design research adalah jenis penelitian yang digunakan untuk merancang dan mengembangkan intervensi (berupa program, strategi dan materi belajar mengajar, produk dan sistem) sebagai suatu solusi untuk permasalahan pendidikan yang kompleks serta untuk meningkatkan pengetahuan kita tentang karakteristik intervensi tersebut serta proses untuk merancang dan mengembangannya, atau sebagai alternatif untuk merancang dan mengembangkan intervensi pendidikan (misalnya proses pembelajaran, lingkungan belajar, dan sejenisnya) dengan tujuan untuk mengembangkan atau memvalidasi teori.

\section{Waktu dan Tempat Penelitian}

Penelitian ini dilaksanakan di kelas VII B SMP Negeri 1 Kadugede pada semester 2 tahun ajaran 2018/2019 dengan waktu penelitian pada tanggal 1 April sampai 30 April 2019.

\section{Subjek Penelitian}

Subjek uji coba pada penelitian pengembangan ini adalah siswa kelas VII B di SMP Negeri 1 Kadugede yang berjumlah sebanyak 31 siswa. Selain itu, subjek validasi perangkat pembelajaran pada penelitian pengembangan ini terdiri dari 3 orang yaitu 1 orang dosen ahli media, 1 orang dosen ahli materi dan 1 orang guru matematika di SMP Negeri 1 Kadugede.

\section{Prosedur}

Pengembangan ini mengacu pada prosedur model pengembangan Plomp yang terdiri tiga fase menurut Ploom (2013) yaitu: (1) Fase Penelitian Pendahuluan (prelimenary investigation); (2) Fase Pembuatan Prototype (Prototyping Phase); (3) Fase Penilaian (Assessment Phase). Pada fase preliminary research terdiri dari analisis masalah yang bertujuan untuk menemukan permasalahan yang terjadi dalam proses pembelajaran maupun hasil pembelajaran dalam lapangan, analisis kurikulum yang bertujuan untuk mengembangkan perangkat pembelajaran yang sesuai dengan kurikulum yang sedang digunakan pada sekolah SMP Negeri 1 Kadugede dan memadukan kurikulum yang digunakan peneliti, analisis siswa yang bertujuan untuk mengetahui karakteristik siswa SMP Negeri 1 Kadugede yang sesuai dengan perangkat pembelajaran yang akan dikembangkan, dan analisis materi pembelajaran ini bertujuan untuk menentukan dan merinci materi pembelajaran yang disusun secara 
sistematis sesuai dengan perangkat pembelajaran yang akan dikembangkan dan disesuaikan dengan waktu peneliti akan melakukan penelitian di sekolah.

Fase pembuatan protoype merupakan fase untuk merancang perangkat pembelajaran untuk mengatasi masalah yang terjadi dalam lapangan. Perangkat pembelajaran yang dikembangkan dinamakan prototype $I$. Kemudian fase penilaian yang terdiri dari dua tahap yaitu validasi perangkat pembelajaran kepada para ahli untuk mengetahui kevalidan dan kepraktisan perangkat pembelajaran dan uji coba terbatas untuk mendapatkan data respon siswa dan data peningkatan kemampuan berpikir kreatif siswa.

Data, Instrumen, dan Teknik Pengumpulan Data

Data yang dikumpulkan pada penelitian ini berupa pemberian angket validasi ahli kepada validator, angket respon siswa setelah proses pembelajaran dan pemberian tes kemampuan berpikir kreatif yang diberikan sebelum dan sesudah proses pembelajaran.

\section{Instrumen Penelitian}

Instrumen yang digunakan untuk memperoleh tanggapan para ahli dan siswa yaitu berupa angket. Dan instrumen untuk mengetahui peningkatan kemampuan berpikir kreatif berupa soal tes kemampuan berpikir kreatif.

\section{Teknik Pengumpulan Data}

Teknik pengumpulan data yang dilakukan pada penelitian ini adalah melalui pemberian angket validasi ahli kepada validator untuk mengetahui kevalidan dan kepraktisan perangkat pembelajaran, pemberian angket respon siswa setelah proses pembelajaran untuk mengetahui respon siswa terhadap perangkat pembelajaran dan pemberian soal tes kemampuan berpikir kreatif yang diberikan sebelum dan sesudah proses pembelajaran untuk mengetahui peningkatan kemampuan berpikir kreatif.

\section{Teknik Analisis Data}

Teknik analisis data yang digunakan pada penelitian ini adalah analisis deskriptif. Untuk mengetahui kevalidan perangkat pembelajaran digunakan analisis statistik deskriptif berdasarkan rata-rata skor dari perangkat pembelajaran yang divalidasi oleh para ahli. Langkah-langkah untuk mentukan rata-rata skor penilaian dari validator adalah sebagai berikut menurut Tanjung dan Nababan (2018).

a. Melakukan rekapitulasi semua pernyataan dari validator ke dalam tabel yang meliputi: aspek $\left(A_{i}\right)$, indikator $\left(I_{i}\right)$, dan nilai $\left(V_{j i}\right)$ untuk tiap-tiap ahli.

b. Mencari rata-rata tiap indikator dari semua validator dengan rumus menurut Tanjung dan Nababan (2018) sebagai berikut:

$$
I_{i}=\frac{\sum_{j=1}^{n} V_{j i}}{n}
$$

Keterangan:

$V_{i j}=$ Data nilai dati penilai ke-j terhadap kategori ke- $i$ $n$ = Banyaknya penilai

c. Mencari rata-rata tiap aspek dengan rumus menurut Tanjung dan Nababan (2018, hlm. 64) sebagai berikut:

$$
A_{i}=\frac{\sum_{j=1}^{n} I_{i j}}{m}
$$


Keterangan:

$A_{i}=$ Rata-rata aspek $-i$

$I_{i j}=$ Rata-rata untuk aspek ke $-i$

indikator ke $-j$

$m$ = Banyaknya aspek

d. Mencari rata-rata total dengan

rumus menurut Tanjung dan

Nababan (2018) sebagai berikut:

$$
V_{a}=\frac{\sum_{i=1}^{n} A_{i}}{n}
$$

Keterangan:

Tabel 1. Deskripsi Kategori Skor Validasi Komponen Perangkat

\begin{tabular}{cc}
\hline Skor Akhir & Kategori \\
\hline$V_{a}=5$ & Sangat Valid \\
\hline $4 \leq V_{a}<5$ & Valid \\
\hline $3 \leq V_{a}<4$ & Cukup Valid \\
\hline $2 \leq V_{a}<3$ & Kurang Valid \\
\hline $1 \leq V_{a}<2$ & Tidak Valid \\
\hline
\end{tabular}

Sumber: Tanjung dan Nababan (2018)

Perangkat pembelajaran

dikatakan valid apabila skor rata-rata total penilaian validator berada dalam kategori minimal valid.

Untuk mengetahui kepraktisan perangkat pembelajaran dilihat dari pernyataan validator terhadap perangkat pembelajaran yang dikembangkan melalui validasi ahli yaitu dikatakan praktis jika validator (para ahli) mengatakan bahwa perangkat pembelajaran tersebut dapat digunakan dengan sedikit revisi atau tanpa revisi (Amir dan Wardana, 2017). Selain itu, kepraktisan perangkat pembelajaran juga dilihat dari respon siswa terhadap perangkat pembelajaran. Teknik analisis
$V_{a}=$ Rata-rata total untuk setiapa spek

$A_{i}=$ Rata-rata aspek ke $-i$

$n$ = Banyaknya aspek

Untuk mencari kategori kevalidan dilakukan dengan cara mencocokkan skor rata-rata total dengan kategori kevalidan perangkat pembelajaran menurut Tanjung dan Nababan (2018) sebagai berikut:

Tabel 2. Kriteria Skor Gain Ternormalisasi

\begin{tabular}{cc}
\hline Skor $\boldsymbol{N}$-Gain & Interpretasi \\
\hline $\mathrm{g}>0,7$ & Tinggi \\
\hline $0,3<\mathrm{g} \leq 0,7$ & Sedang \\
\hline $\mathrm{g} \leq 0,3$ & Rendah
\end{tabular}

Sumber: Hake (1999) 
Kemampuan berpikir kreatif siswa dikatakan meningkat jika perolehan gain ternormalisasai tergolong pada kriteria minimal sedang atau 0,3 $<\mathrm{g} \leq 0,7$ (Lintang dkk, 2017).

\section{HASIL DAN PEMBAHASAN}

Proses Pengembangan Perangkat Pembelajaran

Pada fase penelittian pendahuluan, peneliti melakukan beberapa analisis diantaranya analisis masalah, analisis kurikulum, analisis siswa dan analisis materi pembelajaran.

Berdasar hasil pengamatan di SMP Negeri 1 Kadugede, peneliti menemukan permasalahan yaitu kemampuan berpikir kreatif siswa masih rendah dikarenakan dalam proses pembelajaran masih terpaku kepada guru dan siswa tidak terlibat aktif. kemudian bahan ajar yang digunakan oleh guru juga tidak sepenuhnya memberikan kesempatan kepada siswa untuk mengkonstruksi pengetahuan sendiri, hal ini dikarenakan guru hanya menggunakan bahan ajar yang ada di sekolah tanpa ada usaha untuk merancang atau membuatnya. Seperti dikemukakan Anwar dkk (2015) bahwa guru cenderung menggunakan buku paket yang telah ada tanpa usaha untuk membuat atau mengembangkan yang lainnya sehingga menyebabakan kemampuan berpikir kreatif siswa rendah.

Berdasar Permendiknas No. 20 tahun 2016 bahwa dalam proses pembelajaran siswa harus dapat memiliki kemampuan berpikir kreatif. Oleh karena itu peneliti akan membuat perangkat pembelajaran untuk meningkatkan kemampuan berpikir kreatif. Perangkat pembelajaran juga harus mengacu kepada suatu pendekatan tertentu, pendekatan pembelajaran yang dapat meningkatkan kemampuan berpikir kreatif adalah pendekatan open-ended. Seperti yang dikemukakan oleh Suherman (Dewi, 2017) bahwa tujuan pembelajaran openended tiada lain adalah agar kemampuan berfikir matematika siswa dapat berkembang secara maksimal dan pada saat yang sama kegiatan-kegiatan kreatif dari setiap siswa terkomunikaiskan melalui proses belajar mengajar. Sehingga pendekatan pembelajaran yang dapat meningkatkan kemampuan berpikir kreatif siswa adalah pendekatan open-ended.

Hasil analisis kurikulum, sekolah tersebut menggunakan kurikulum 2013 revisi. Pendekatan open-ended sesuai dengan karakteristik dari kurikulum 2013 yaitu menurut Rini (2018) pendekatan open-ended merupakan pembelajaran berbasis student center dengan pengajuan masalah. Masalah disini yaitu masalah yang mempunyai banyak jawaban benar atau banyak cara penyelesaian sehingga siswa dapat mengkonstruksi pengetahuan dengan cara sendiri dan dengan berbagai cara penyelesaian.

Analisis siswa terhadap kemampuan berpikir kreatif masih terbilang rendah berdasar hasil pengamatan proses pembelajaran masih berlangsung dengan menggunakan metode ceramah, siswa kurang terlibat aktif dan masih banyak siswa yang sulit menerima atau memahami materi yang disampaikan oleh guru dalam proses 
pembelajaran. Sehingga untuk mengatasi masalah tersebut, maka perlu dikembangkan pembelajaran matematika yang dapat memberikan keleluasaan perserta didik untuk belajar berpikir secara aktif dan mungkin dalam memecahkan masalah yang dihadapi, salah satunya pembelajaran dengan menggunakan modul. Pembelajaran dengan modul akan lebih efektif dan efisien dibandingkan dengan pembelajaran menggunakan metode ceramah yang cenderung bersifat klasikal dan dilaksanakan dengan tatap muka (Anggoro, 2015). Dengan menggunakan perangkat pembelajaran berupa modul berbasis pendekatan open-ended siswa mengkonstruksi sendiri konsep materi yang dipelajari dengan menggunakan berbagai cara penyelesaian yang menyebabkan siswa terlibat aktif selama proses pembelajaran sehingga siswa akan mudah menerima materi pembelajaran yang akan dipelajari.

Analisis materi pelajaran yang akan dilakukan oleh peneliti, menurut Hidayanto dan Khalistin (2013) salah satu materi dalam matematika yang dapat disampaikan melalui pendekatan pembelajaran open-ended adalah materi geometri yaitu tentang segiempat, karena dalam materi segiempat terdapat rumus-rumus untuk menghitung keliling dan luas bangun datar segiempat dengan menggunakan banyak metode atau cara memperolehnya. Hal ini juga dipertimbangkan dengan waktu peneliti akan melakukan penelitian di sekolah tersebut sehingga materi yang dipilih adalah materi bangun datar segiempat yang terdiri dari persegi panjang, persegi, jajargenjang, trapesium, belahketupat dan layang-layang.

Berdasar hasil analisis di atas, peneliti membuat sebuah pengembangan perangkat pebelajaran yang dapat meningkatkan kemampuan berpikir kreatif siswa, bentuk dari perangkat pembelajaran yang dikembangkan adalah modul pembelajaran siswa dan Rencara Pelaksanaan Pembelajaran (RPP) pada materi segiempat yang disesuaikan dengan prosedur pendekatan open ended.

Selanjutnya pada fase
pembuatan pototype, dibuat dan
dirancang perangkat pembelajaran sebagai solusi dari permasalahan yang terjadi. Setelah perangkat pembelajaran atau prototype $I$ selesai dirancang. Kemudian pada fase penilaian perangkat pembelajaran divalidasi kepada validator untuk menentukan kevalidan dan kepraktisan perangkat pembelajaran yang dikembangkan dan diperbaiki sesuai saran dan koreksi dari para validator sehingga diperoleh prototype II yang siap di uji coba di lapangan.

\section{Kevalidan Perangkat Pembelajaran}

Perangkat pembelajaran divalidasi oleh 3 orang validator yaitu 2 orang dosen pendidikan matematika dan 1 orang guru mata pelajaran matematika kelas VII di SMP Negeri 1 Kadugede. Perangkat pembelajaran dikatakan valid jika rata-rata skor total dari ketiga validator berada dalam kategori valid. Validasi RPP dilihat dari 9 aspek penilaian yaitu aspek identitas, perumusan indikator, perumusan tujuan pembelajaran, pemilihan materi ajar, 
pemilihan sumber belajar, pemilihan media belajar, pendekatan pembelajaran, kegiatan pembelajaran dan penilaian/evaluasi. Rata-rata penilaian validator pada RPP untuk ke enam pertemuan disajikan pada tabel berikut.

Tabel 3. Hasil Validasi Rencana Pelaksanaan Pembelajaran

\begin{tabular}{ccc}
\hline Pertemuan Ke- & Rata-Rata Validitas & Keterangan \\
\hline Pertemuan ke-1 & 4,32 & Valid \\
\hline Pertemuan ke-2 & 4,32 & Valid \\
\hline Pertemuan ke-3 & 4,34 & Valid \\
\hline Pertemuan ke-4 & 4,26 & Valid \\
\hline Pertemuan ke-5 & 4,24 & Valid \\
\hline Pertemuan ke-6 & 4,26 & Valid \\
\hline Rata-Rata Keseluruhan & $\mathbf{4 , 2 9}$ & Valid \\
\hline
\end{tabular}

Berdasar tabel di diatas diperoleh bahwa penilaian validator terhadap RPP untuk keenam pertemuan memperoleh kategori valid dan secara keseluruhan memperoleh hasil 4,29 dengan kriteria valid (Tanjung dan Nababan, 2018). Validasi modul dilihat dari 5 aspek yaitu aspek materi, penyajian, kegrafikan, kebahasaan dan karekteristik pendekatan open-ended. Rata-rata penilaian validator pada modul secara keseluruhan memperoleh hasil 4,33 dengan kriteria valid (Tanjung dan Nababan, 2018).

\section{Kepraktisan}

Perangkat

\section{Pembelajaran}

Penilaian validator terhadap RPP dan modul yang dikembangkan yaitu dapat digunakan tanpa revisi dan dapat digunakan dengan sedikit revisi. Hal ini menunjukan bahwa perangkat pembelajaran berada dalam kategori praktis (Amir dan Wardana, 2017). Namun terdapat sedikit revisi sehingga perangkat pembelajaran tersebut direvisi terlebih dahulu sesuai saran validator sebelum diujicobakan di sekolah. Revisi kecil dari para validator meliputi perbaikan kesalahan penulisan kata, perbaikan beberapa gambar yang kurang jelas dan tampilan bagian cover modul agar tidak terkesan ramai. Karena perangkat pembelajaran yang dikembangkan telah memenuhi kriteria praktis sehingga validasi ahli perangkat pembelajaran ini hanya dilakukan satu kali saja.

Hasil analisis respon siswa terhadap perangkat pembelajaran yang dikembangkan sebesar 92,56\% menjawab setuju dan sangat setuju terhadap pernyataan yang diberikan sehingga respon siswa terhadap perangkat pembelajaran berada dalam kategori positif (Anwar dkk, 2015). Namun masih ada beberapa siswa yang tidak memberikan respon positif atau memberikan jawaban tidak setuju dari pernyataan yang diberikan. Salah satu pernyataannya adalah "modul ini membantu saya memahami materi segiempat". Terdapat 4 orang yang menjawab tidak setuju pada aspek tersebut. Hal ini menunjukan bahwa masih ada siswa yang belum memahami isi dari modul, dikarenakan siswa masih merasa baru dengan proses pembelajaran yang berpusat kepada 
siswa dimana siswa harus mengkonstruksi konsep materi sendiri. Hasil ini sejalan dengan penelitian yang dilakukan Saputro dkk (2015) dalam mengembangkan perangkat pembelajaran untuk meningkatkan kemampuan berpikir kreatif bahwa berdasar hasil angket respon siswa diperoleh masih ada siswa yang merasa baru terhadap suasana belajar yang dilatihankan guru dan cara mengajar guru. Siswa belum terbiasa menemukan sendiri konsep materi pembelajaran dan mengerjakan permasalahan yang diberikan oleh guru dengan menggunakan banyak cara penyelesaian atau dengan memberikan banyak jawaban benar. Akan tetapi 27 dari 31 atau $87,10 \%$ siswa di kelas tersebut menyatakan bahwa pembelajaran matematika melalui modul pendekatan open-ended ini membantu dalam memahami materi segiempat.

\section{Peningkatan Kemampuan Berpikir Kreatif}

Hasil analisis uji N-Gain memperoleh rata-rata sebesar 0,67 dengan kriteria peningkatan "sedang" (Hake, 1999). Sehingga dapat disimpulkan bahwa terjadi peningkatan kemampuan berpikir kreatif terhadap pembelajaran menggunakan perangkat pembelajaran open-ended (Lintang dkk, 2017). Peningkatan kemampuan berpikir kreatif siswa yang masih tergolong dalam kategori sedang dimungkinkan salah satu penyebabnya adalah siswa masih merasa baru dengan kegiatan pembelajaran yang dilaksanakan dimana guru bukan merupakan pusat pembelajaran di kelas. Namun hal ini hanya terjadi di awal pembelajaran saja, untuk pembelajaran selanjutnya siswa menjadi lebih aktif dan dapat mengeksplorasi pengetahuan mereka dalam menyelesaikan permasalahan dengan memberikan banyak jawaban benar dan menggunakan banyak cara penyelesaian. Hal ini sesuai dengan respon siswa terhadap modul pembelajaran bahwa 96,77\% siswa memberikan respon setuju dan sangat setuju terhadap pernyataan 'kegiatan yang ada di modul membantu saya meningkatkan hasil belajar saya'. Sehingga dapat disimpulkan bahwa perangkat pembelajaran pendekatan open-ended dapat meningkatkan hasil belajar siswa dengan perolehan peningkatan uji n-gain sebesar 0,67.

\section{SIMPULAN DAN SARAN Simpulan}

Kesimpulan dari penelitian ini adalah sebagai berikut: 1) proses pengembangan perangkat pembelajaran melalui pendekatan open-ended ini dilakukan menggunakan model Ploomp denga 2 fase yaitu fase penelitian pendahuluan, fase pembuatan prototype dan fase penilaian. 2) Perangkat pembelajaran yang dikembangkan memenuhi kriteria valid dilihat dari rata-rata total penilaian validator 3) Perangkat pembelajaran yang dikembangkan memenuhi kriteria praktis dengan pernyataan validator bahwa perangkat pembelajaran dapat digunakan dengan sedikit revisi dan tanpa revisi, dan respon siswa terhadap perangkat pembelajaran adalah positif.

4) Terdapat peningkatan kemampuan berpikir kreatif didasarkan pada 
perhitungan $\mathrm{N}$-Gain yang ditinjau dari kenaikan tes sebelum dan sesudah proses pembelajaran pada kategori sedang.

\section{Saran}

Berdasarkan hasil yang telah disimpulkan dari hasil penelitian ini, maka penulis memiliki beberapa saran terkait perangkat pembelajaran yang dikembangkan, yaitu sebagai berikut:

1. Perangkat pembelajaran yang dikembangkan hanya berbentuk RPP dan buku modul,sehingga peneliti selanjutnya bisa menambahkan bentuk perangkat pembelajaran lainnya.

2. Animasi yang digunakan dalam buku modul siswa masih sedikit, hal ini dikarenakan keterbatasan kemampuan peneliti.

3. Materi yang disajikan dalam buku modul siswa terbatas hanya pada subtema bangun datar segiempat dan untuk peneliti selanjutnya bisa ditambah dengan materi lainnya sesuai dengan jenjang pendidikan yang sedang ditempuh.

4. Prosedur model pembelajaran yang digunakan menggunakan prosedur pendekatan open-ended. Sehingga untuk penelitian selanjutnya bisa menambahkan model lainnya kedalam perangkat pembelajaran ini yang sesuai dengan karateristik siswa.

\section{DAFTAR PUSTAKA}

Affandi, A. dkk. (2013). Pendekatan Open-Ended dan Inkuiri Terbimbing ditintau dari Kemampuan Pemecahan Masalah dan Representasi Multipel Matematis.
PYTHAGORAS : Jurnal Pendidikan Matematika. Vol 8. No 1. hal 1-11.

Anggoro, B. S. (2015). Pengembangan Modul Matematika dengan Strategi Problem Solving untuk Mengukur Tingkat Kemampuan Berpikir Kreatif Matematis Siswa. Jurnal Pendidikan Matematika. Vol 6. No 2.

Anwar, N. dkk. (2015). Pengembangan Perangkat Pembelajaran Berbasis Pendekatan OpenEnded untuk Meningkatkan Kemampuan Berfikir Kreatif Matematis Siswa SMP. Jurnal Didaktis Matematika. Vol. 2. No 1.

Anwar , N. M. et al. (2012). Relationship of Creative Thinking with Academc Achievements of Secondary School Students. International Interdiciplinary Journal of Education. Vol 1. No 3.

Amir, M. F. \& Wardana, M. D. K. (2017). Pengembangan Domino Pecahan Berbasis Open-Ended untuk Meningkatkan Kemampuan Berpikir Kreatif Siswa SD. Jurnal Pendidikan Matematika FKIP Univ. Muhammadiyah Metro. Vol 6. No 2.

Ariani, A. dkk. (2013). Pengembangan Perangkat Pembelajaran Geometri SMP dengan Pendekatan Open-ended Berorientasi Kemampuan Berfikir Kritis. PHYTAGORAS:Jurnal Pendidikan Matematika. Vol 8. No 1. Hal 21-32.

Dewi, P. K. (2017). Pengembangan Perangkat Pembelajaran dengan Pendekatan Saintifik Berorientasi Masalah Open- 
ended untuk Meningkatkan Kemampuan Berfikir Kreatif Siswa pada Materi Segiempat. Pendidikan Matematika. Vol 6. No 8.

Faridah, N, dkk. (2016). Pendekatan Open-ended untuk Meningkatkan Kemampuan Berpikir Kreatif Matematis dan Kepercayaan Diri Siswa. jurnal Pena Ilmial. Vol 1. No 1.

Hake, R.R. (1999). Analyzing Change/Gain Scores. Woodland Hills: Dept. of Physics, Indiana University. [Online]. Tersedia: http://www.physics.indiana. edu/ sdi/AnalyzingChangeGain.pdf [11 Februari 2019]

Hidayanto, E. \& Khalistin, R. A. (2013). Penerapan Pendekatan Open-Ended untuk Meningkatkan Pemahaman Siswa Kelas VII A di SMP Negeri Batu pada Materi Segiempat. Jurnalonline.um.ac.id.

Indraningtias, D., A. dan Wijaya, A. (2017).

Pengembangan

Perangkat Pembelajaran

Berbasis Pendekatan

Matematika realistik Materi Bangun Ruang Sisi Data Berorientasi pada Kemampuan Berpikir Kritis Siswa Kelas VIII SMP. Jurnal Pendidikan Matematika. 6(5). 24-36

Lestari, K. E. \& Yudhanegara, M. R. (2015). Penelitian Pendidikan Matematika. Bandung: PT Refika Aditama.

Lintang, A. C. dkk. (2017). PBL dengan APM untuk Meningkatkan Kemampuan Pemrcahan Masalah dan Sikap Percaya Diri. Journal of Primary
Education. Vol 6. No 1. Hal 27-34.

Mursidik, E. M. dkk. (2015). Kemampuan Berpikir Kreatif dalam Memecahkan Masalah Matematika Open-Ended ditinjau dari Tingkat Kemampuan Matematika pada Siswa Sekolah Dasar. Jurnal Pedagogia. Vol 4. No 1.

Novtiar, C. \& Aripin, U. (2017). Meningkatkan Kemampuan Berpikir Kritis Matematis dan Kepercayaan Diri Siswa SMP Melalui Pendeketan OpenEnded. Jurnal Prisma Universitas Suryakanca. Vol 6. No. 2.

Peraturan Mentri Pendidikan dan Kebudayaan Nomor 20 (2016). Standar Kompetensi Lulusan Pendidikan Dasar Dan Menengah. Jakarta: Kemendikbud.

Plomp, et all. (2013). Educational Desain Researc.

Enschede:SLO.

Rini (2018). Pengaruh Pendekatan Open-Ended Terhadap

Kemampuan Berpikir Intuitif Matematis Siswa. Skripsi. Universitas Islam Syarif Hidayatullah.

Rochmad. (2012). Desain Model Pengembangan Perangkat Pembelajaran Matematika. Jurnal Kreano. Vol 3. N0 1.

Santi, I. K. L \& Santosa. (2016). Pengembangan Perangkat Pembelajaran Menggunakan Pendekatan Saintifik pada Materi Pokok Geometri Ruang SMP. PHYTAGORAS: Jurnal Pendidikan Matematika. Vol 11. No 1. Hal 35-44.

Saputro, R. P. dkk. (2015). Pengembangan Perangkat Pembelajaran Model Discovery 
Learning untuk Meningkatkan Hasil belajar dan Keterampilan Berpikir Kreatif. Pendidikan Pasca Sarjana Universitas Negeri Surabaya. Vol 5. No 1.

Suryadinata, N. (2015). Pengembangan Perangkat Pembeajaran Strategi Quick on the Draw dengan Masalah Open-ended untuk Meningkatkan Kemampuan Berfikir Kreatif Materi Prisma dan Limas. Jurnal Pendidikan Matematika FKIP Univ. Muhammadiyah Metro. Vol 4. No 1. Hal 9-21.

Soeyono, Y. (2014). Pengembangan Bahan Ajar Matematika dengan Pendekatan Open- ended untuk Meningkatkan Kemampuan Berfikir Kritis dan Kreatif siswa SMA. PHYTAGORAS : Jurnal Pendidikan Matematika. Vol 9. No 2. Hal 205-218.

Tanjung, H. S. \& Nababan, S. A. (2018).

Perangkat

Pengembangan

Berorientasi

Matematika

Pembelajaran Model

Masalah (PBM) untuk Meningkatkan Kemampuan Berpikir Kritis Siswa SMA seKuala Nagan Raya Aceh. Genta Mulia: Jurnal Ilmiah Pendidikan. Vol 9. No 2. Hal 56. 
